\title{
COMPUTER MODELLING OF THE STRESS-STRAIN STATE OF PLUG-IN CONNECTIONS OF REINFORCED CONCRETE COLUMNS WITH THE COVERAGE PLATES UNDER THE OUT-OF-SQUARE ECCENTRIC COMPRESSION
}

\author{
Boris S. Sokolov ${ }^{1}$, Evgeniy O. Troshkov ${ }^{2}$ \\ ${ }^{1}$ Joint Stock Company "Kazan Giproniiaviaprom", Kazan, RUSSIA \\ ${ }^{2}$ Povolzhsky State Technological University, Yoshkar-Ola, RUSSIA
}

\begin{abstract}
The technique and results of computer simulation of the stress-strain state of plug joints of reinforced concrete columns with overlap plates under the effect of out-of-square eccentric compression are described. An analysis of the results obtained is provided to optimize the experimental research plan and to develop a technique for calculating the strength of the joints used in the UICSS bearing system.
\end{abstract}

Keywords: numerical methods, finite element method, reinforced concrete structures, plug-in joint, stress-strain state

\section{КОМПЬЮТЕРНОЕ МОДЕЛИРОВАНИЕ НАПРЯЖЕННО-ДЕФОРМИРОВАННОГО СОСТОЯНИЯ ШТЕПСЕЛЬНЫХ СТЫКОВ ЖЕЛЕЗОБЕТОННЫХ КОЛОНН С ПЛИТАМИ ПЕРЕКРЫТИЯ ПРИ КОСОМ ВНЕЦЕНТРЕННОМ СЖАТИИ}

\author{
Б.С. Соколов ${ }^{1}$, Е.О. Троиков ${ }^{2}$ \\ ${ }^{1}$ Акционерное общество «Казанский Гипронииавиапром», г. Казань, РОССИЯ \\ ${ }^{2}$ Поволжский государственный технологический университет, г. Йошкар-Ола, РОССИЯ
}

\begin{abstract}
Аннотация: В статье описывается методика и результаты выполненного компьютерного моделирования напряженно-деформированного состояния штепсельных стыков железобетонных колонн с плитами перекрытия при действии косового внецентренного сжатия. Приводится анализ полученных результатов, необходимый для оптимизации плана экспериментальных исследований и разработки методики расчета прочности изучаемых стыков, применяемых в несущей системе «УИКСС».
\end{abstract}

Ключевые слова: численные методы, метод конечных элементов, железобетонные конструкции, штепсельный стык, напряженно-деформированное состояние

\section{INTRODUCTION}

The construction of buildings using prefabricated reinforced concrete frame systems is widely used in the territory of the Russian Federation, since it minimizes the labor and financial costs of their erection, and also shortens construction time. The development of technologies promotes the use of new variants of constructive framing solu- tions, one of which is the precast reinforced concrete bearing system with beamless floor "UIKSS" ("Universal Industrial Frame Construction System") (Figure 1) [1]. A feature of such a frame is the use of plug-in joints for connecting floor slabs to columns.

The proposed joint (Figure 2) is a structure in which the lower column (1) has the outlets (2), in the plate (5) are located the holes (6) for placing these rods, and the upper column (3) is equipped 
Dissipative Systems Computer Modelling of the Stress-Strain State of Plug-In Connections of Reinforced Concrete Columns with the Coverage Plates Under the Out-of-Square Eccentric Compression

with boreholes (4), which, when mounted through special holes (7), are injected with a grouting compound. Prior to installation, steel or synthetic (polymeric) centering gaskets (8) are installed on the bottom column and plate.

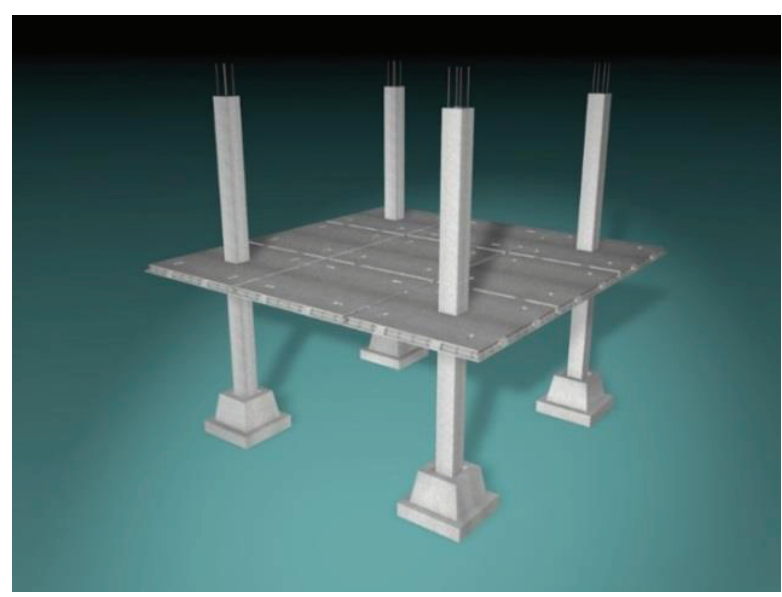

Figure 1. General view of the base cell of the frame system "UIKSS".

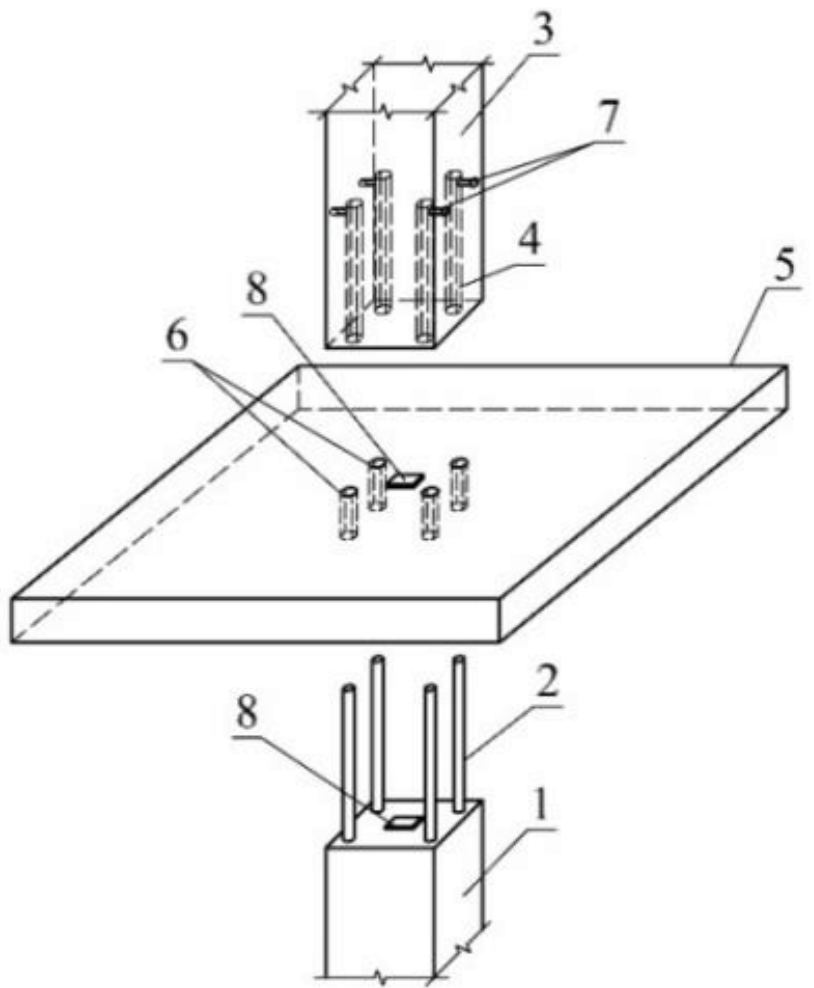

Figure 2. General view of the column joint with a slab.

The "UIKSS" system is applicable for the design and construction of low-rise private, residential multi-apartment and public buildings, school and preschool institutions, as well as for the reconstruction of buildings and structures [2,3, etc.].

The introduction of the proposed frame system is hampered by the absence in the scientific and technical literature on methods for calculating the strength and deformation of the plug joints located in the zone of action of longitudinal and transverse forces and bending moments, therefore for the development of such techniques it is necessary to conduct stress-strain analysis (SSA) of the joints. The study of SSA data of joints includes theoretical, numerical and experimental studies.

\section{FORMULATION OF RESEARCH PROBLEMS}

The analysis of available scientific, technical and normative literature allowed the authors to divide the joints studied into three types depending on their location in the overlap and on the resulting combinations of forces:

- medium, located in the middle part of the overlap, where the compressive forces with random eccentricity mainly act;

- extreme, connecting the overlapping plates with columns of the extreme row and perceiving longitudinal and transverse forces and bending moments;

- angular, perceiving longitudinal forces, as well as transverse forces, bending and twisting moments in two directions.

In $[4,5$, etc. $]$ the results of the study of medium and extreme joints are published. This article is devoted to the study of the SSA of corner joints with oblique eccentric compression with the use of computer modeling. The most relevant studies in this area are the work of T.S. Evdokimova, dedicated to the SSA of skew-collapsible fiber-reinforced concrete elements and made under the supervision of the Doctor of Technical Sciences, Professor V.I. Morozov [6,7]. The difference between the author's studies is the study of the SSA of the contact zone of reinforced concrete joint elements under the action of oblique eccentric compression. 
Numerical studies were carried out in the PC LIRA-SAPR 2013 R3 implementing the finite element method (FEM) and possessing the necessary functionality for solving the set tasks, including:

- obtaining data on destruction schemes, distribution of stresses in concrete and strength of the joint, as well as its individual elements;

- determination of geometric characteristics of the calculated zones of concrete structures and stresses arising in the reinforcement;

- identify the features of the SSA elements of the joint, taking into account the effect of a combination of loads on the column and slab;

- optimization of the program for conducting physical experiments and reducing the costs of their implementation.

\section{METHODOLOGY OF RESEARCH}

Numerical studies were carried out taking into account the physical nonlinearity of materials. In the modelling, we used volume isoparametric finite elements (FE) of type 236 and 234 and universal spatial rod FE - type 410.

The physical and mechanical characteristics of concrete were modeled according to the law of deformation of GA. Geniev [8]. The design resistance of the material to compression and stretching, as well as ultimate deformations, were taken according to the current norms [9]. The stiffness characteristics of reinforcing steel were described by two-line diagrams [9].

One of the important issues in the simulation of the SSA of reinforced concrete structures is the issue of the coupling of reinforcing bars to concrete [10 - 12], and in the study of the work of plug joints - the coupling of reinforcing elements with the injection of wells. Analysis of the literature showed that this problem can be solved using various computational models of FEM [13 \pm 15]. In the numerical studies carried out, the adhesion of the reinforcement to the concrete and the injection solution is realized by simulating common nodes of elements, without assigning additional boundary conditions.
The simulation was carried out with a step-by-step increase in the load, allowing the structures to be brought to virtual destruction, which is necessary to evaluate the SSA of the joint elements at each loading stage. Criteria for failure were the attainment of limiting stress values along the main areas in the group of bulk FEs, the yield stress in reinforcing bars, and the transition of the system to a geometrically variable one.

To model and study SSA of the joint it was necessary to determine the possible values of eccentricities under the action of external loads. To solve this problem, static calculations of 2-, 3-, 4, 5-, and 6-storey double-span building schemes loaded with vertical loads were performed earlier. The performed calculations showed that for angular joints the greatest values of the eccentricities of the longitudinal force arise in the coating level,

$$
\frac{e_{0 x}}{h}=1,68 ; \frac{e_{0 y}}{h}=1 .
$$

Eccentricities in joints of other floors are within

$$
\frac{e_{0 x}}{h}=0,09 \ldots 0,44 ; \frac{e_{0 y}}{h}=0,06 \ldots 0,25
$$

The obtained data allow carrying out numerical studies of SSA.

Samples in the numerical studies carried out had the parameters shown in Figure 3. A general view of the FEM of the joint is shown in Figure 4. The maximum geometric dimensions of volumetric FE columns are taken as $25 \times 25 \times 20 \mathrm{~mm}$. Wells were modeled by volumetric FE with six nodes converging at the central point and simulating the cylindrical shape (see Fig. 4, b).

In the framework of numerical studies of the SSA with out-of-square eccentric compression, calculations of the ES-II-5 and ES-II-5.1 series samples were performed. Variable parameters and research tasks are shown in Table 1.

The models of the ES-II-5 series were calculated under the action of constant values of the uniformly distributed vertical load on the overlap $(q=$ $\left.4 \mathrm{kN} / \mathrm{m}^{2}\right)$ and horizontal loads applied to the slab in two directions $\left(Q_{x}=Q_{y}=40 \mathrm{kN}\right)$. 
Dissipative Systems Computer Modelling of the Stress-Strain State of Plug-In Connections of Reinforced Concrete Columns with the Coverage Plates Under the Out-of-Square Eccentric Compression

Table 1. Variable parameters and research problems.

\begin{tabular}{|c|c|c|c|}
\hline Model family & Real load & Variable feature & Research objectives \\
\hline ES-II-5 & $\begin{array}{l}q=4 \mathrm{kN} / \mathrm{m}^{2} \\
Q_{x}=Q_{y}=40 \mathrm{kN} \\
N \text { - step-up }\end{array}$ & \multirow{2}{*}{$\begin{array}{l}\text { a) } e_{O X} / h=e_{O Y} / h= \\
0.125 \\
\text { b) } e_{0 X} / h=e_{O Y} / h= \\
0.25 \\
\text { c) } e_{O X} / h=e_{O Y} / h= \\
0.375\end{array}$} & \multirow{2}{*}{$\begin{array}{l}\text { Definition of: } \\
\text { - destruction schemes; } \\
\text { - geometric characteristics of the } \\
\text { calculated zones of the contact } \\
\text { zone according to the theory of } \\
\text { the resistance of anisotropic } \\
\text { materials to compression; } \\
\text { - stresses in armature, straps } \\
\text { made of steel strip, indirect re- } \\
\text { inforcement mesh }\end{array}$} \\
\hline ES-III-5.1 & $\begin{array}{l}q=0 \mathrm{kN} / \mathrm{m}^{2} \\
Q_{x}=Q_{y}=0 \mathrm{kN} \\
N \text { - step-up }\end{array}$ & & \\
\hline
\end{tabular}

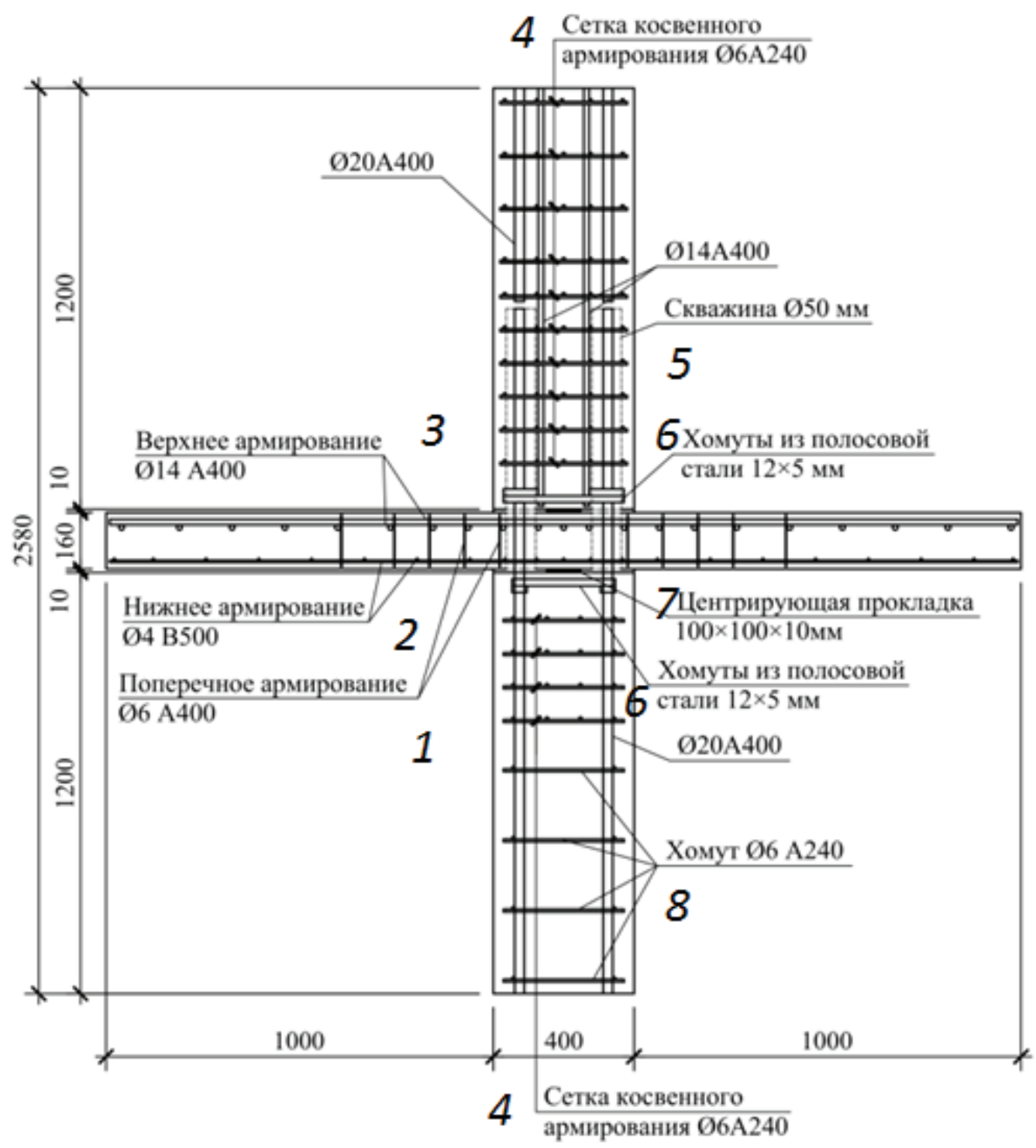

Figure 3. Geometric dimensions and reinforcement scheme for simulated samples:

1 - lateral reinforcement; 2 - bottom reinforcement; 3 - top reinforcement;

4 - grid of confinement reinforcement; 5 - cored hole; 6 - yokes from strap iron; 7 - aligning gasket; 8 -yoke. 
a)

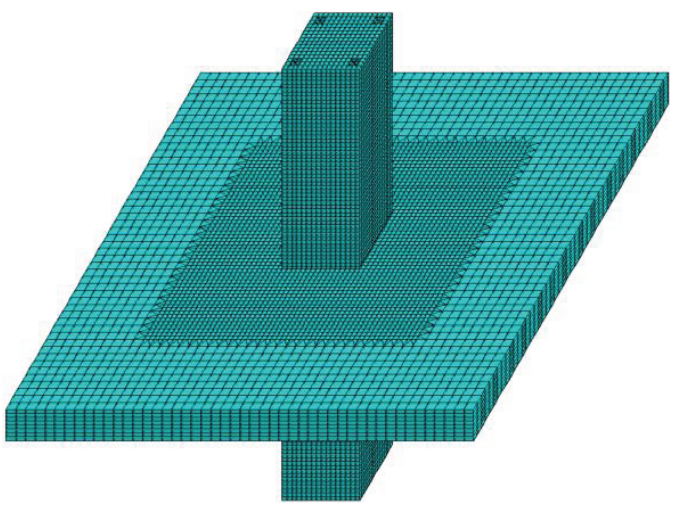

b)

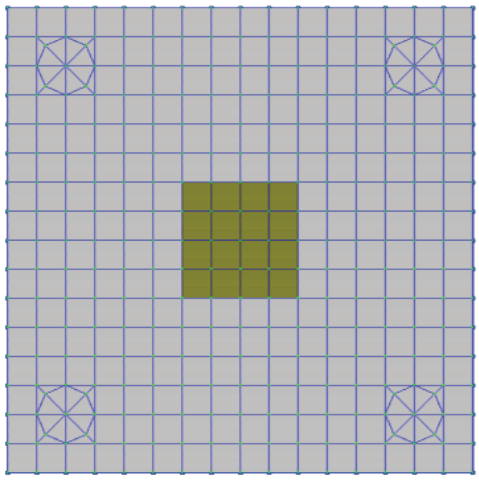

Figure 4. Finite-element design model of the joint: a - general view; $b$ - column with centering gasket (top view).
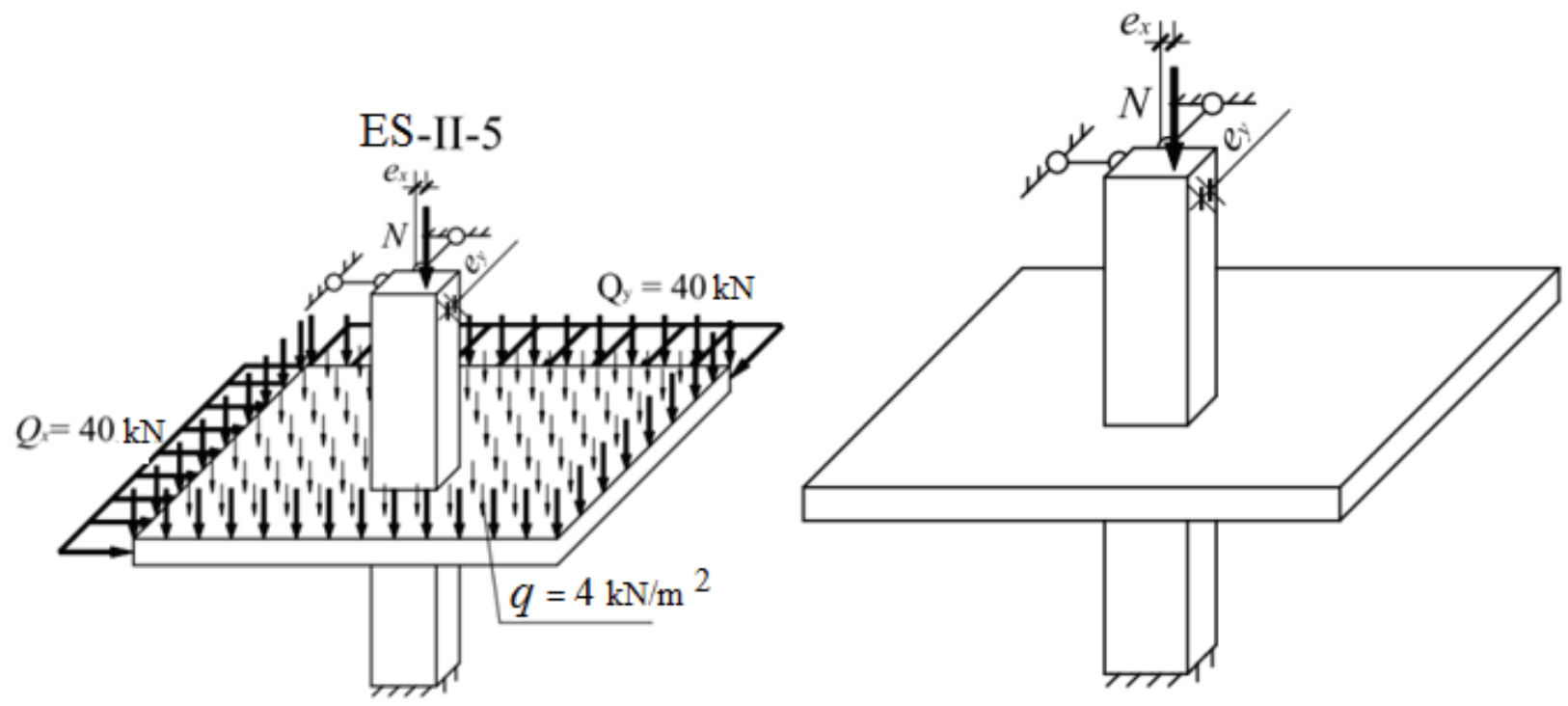

Figure 5. Loading scheme for models ES-II-5 and ES-II-5.1.

In this case, a step-by-step increase in the vertical load on the column with different values of eccentricity and bringing the model to destruction was performed (Figure 5).

\section{ANALYSIS OF THE RESULTS OF THE RESEARCH}

The destruction pattern of ES-II-5 and ES-II-5.1 series samples should be characterized as the achievement of the endurance strength of the end sections of the columns in the contact zone. The analysis of the principal stresses and the failure scheme showed that their SSA corresponds to the theory of the strength resistance of anisotropic materials to compression [16], while the triaxle compression zone is displaced along the $x$ and $y$ axes by equal distances with respect to the center of the section, and the slope angles of the wedge $\alpha$ correspond to the theoretical ones [16].

The results of modeling of the ES-II-5 series made it possible to reveal a feature that the geometric characteristics of the calculated zones of the end sections of the upper and lower columns (the wedge height $h_{k}$ and the width of the $L_{l o c}$ load transfer zone) are different. The values of these parameters in the upper column coincide with those obtained in the simulation of eccentric compression with eccentricity of one direction, and in the lower column have large values (Figure 6). 
Dissipative Systems Computer Modelling of the Stress-Strain State of Plug-In Connections of Reinforced Concrete Columns with the Coverage Plates Under the Out-of-Square Eccentric Compression
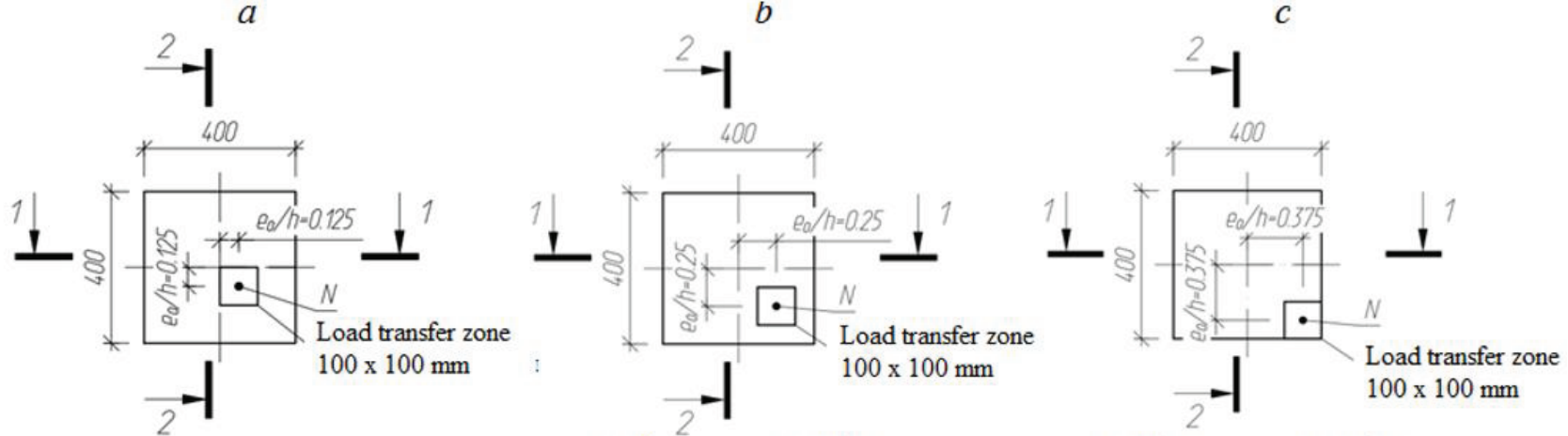

Section 1-1 Section 2-2
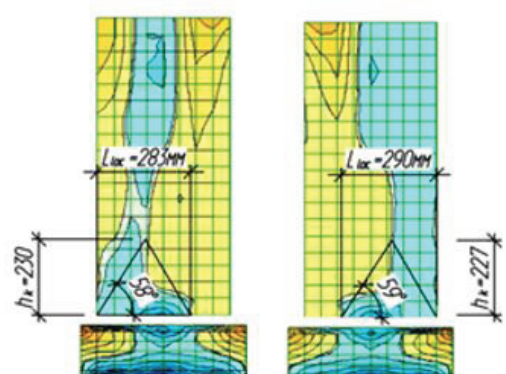

Section 1-1

Section 2-2

Section 1-1

Section 2-2
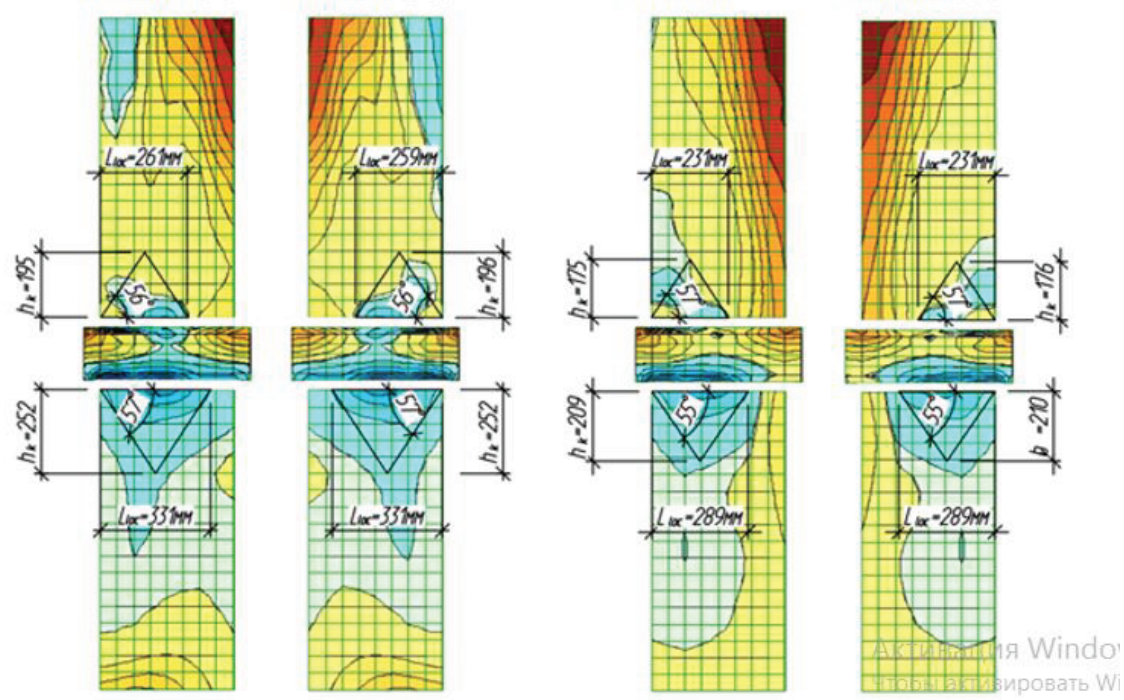

Figure 6. Isofields of principal stresses $\sigma 1$ in sections 1-1 and 2-2 of samples ES-II-5: a -eOX/h $=e 0 Y / h=0.125 ; b-e 0 X / h=e 0 Y / h=0.25 ; c-e 0 X / h=e 0 Y / h=0.375$.

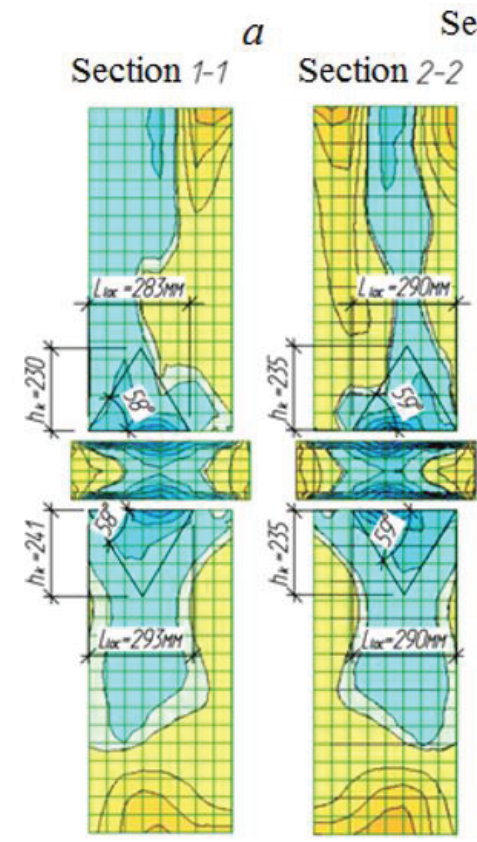

Section

$b$

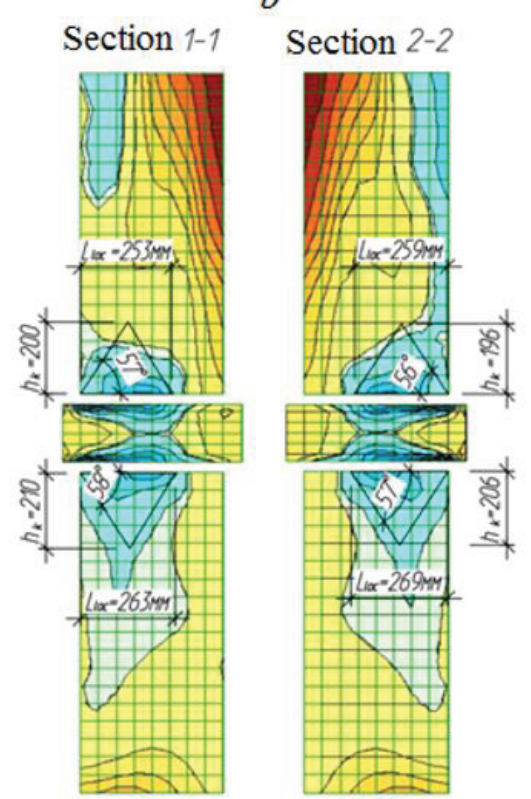

$c$

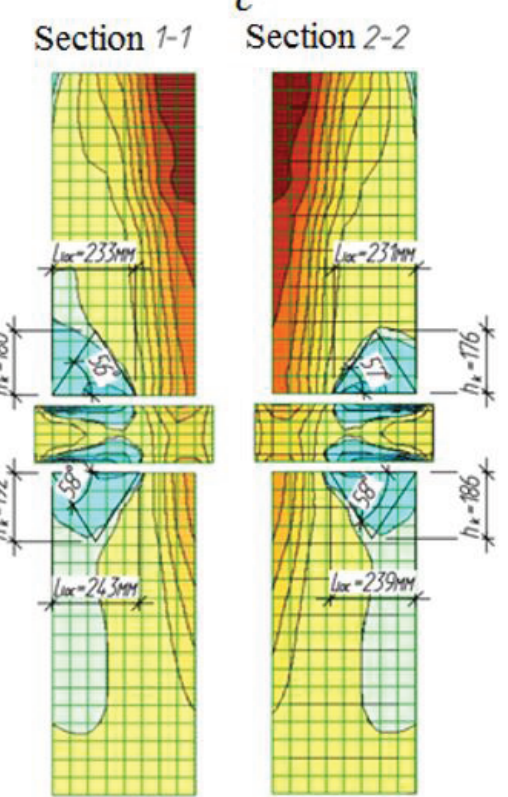

Figure 7. Isofields of principal stresses $\sigma 1$ in sections 1-1 and 2-2 of ES-II-5.1 samples: $a-e 0 X / h=e 0 Y / h=0.125 ; b-e 0 X / h=e 0 Y / h=0.25 ; c-e 0 X / h=e 0 Y / h=0.375$. 
The calculated concrete areas of the end sections of the columns have different geometric dimensions, because a vertical evenly distributed load applied to the overlap plate causes the element to bend, thereby further "squeezing" the upper end of the lower column, causing an increase in the triaxle compression zone.

This conclusion is confirmed by the isofields of the principal stresses obtained by calculation of the ES-II-5.1 series models, according to which the geometric sizes of the calculated zones of the upper and lower columns have low divergences of absolute values (Figure 7).

Analysis of stresses in the reinforcing bars of the ES-II-5 and ES-II-5.1 series models showed that in the corner rod of the longitudinal reinforcement of the columns closest to the load application area, stresses at breakdown reach a yield point. The values of compressive stresses in the remaining rods are lower, and at eccentricities of 0.25 and 0.375 in the opposite angular rods tension was observed. It is determined that the steel strips yokes crossing the area of concrete shear experience tensile forces and should be taken into account in the calculation expressions. Tensile forces are also fixed in the grids of the indirect columns crossing the plane of detachment of concrete [16].

Thus, the obtained data on SSA of the joint allow us to develop the necessary methodology for calculating the strength with oblique eccentric compression.

\section{CONCLUSIONS}

The computer simulation of the SSA of the plug joints of the slabs with columns of the precast reinforced-concrete frame system "UIKSS" under the action of out-of-square eccentric compression made it possible to formulate the following conclusions.

1. The destruction schemes and the tensioning isofield confirm the possibility of applying the theories of the force resistance of anisotropic materials to compression for the development of a technique for calculating the strength of the joint with out-of-square eccentric compression based on the evaluation of the strength of the end sections of the columns.

2. The characteristics of the calculated zones of concrete $\left(L_{l o c}, h_{p}, \alpha\right)$ and stresses arising in the reinforcement elements necessary for the development of the strength calculation procedure are determined.3. It was found that with out-of-square eccentric compression taking into account vertical loads acting on the slab, the zone of triaxle compression of the end portion of the lower column increases due to bending of the plate, increasing the strength of the element.4. Taking into account the obtained results, it is possible to optimize the plan of experimental studies of joint SSA in the operational stage with out-of-square eccentric compression.

\section{REFERENCES}

1. Universal'naja Industrial'naja Karkasnaja Sistema Stroitel'stva - Tatarstan (UIKSSTatarstan) [Universal industrial frame construction system] - Tatarstan (UIKSS-Tatarstan): pat. 141473 Rossijskaja Federacija: MPK E04V1/20 / Sokolov B.S.; zajavitel' i patentoobladatel' Sokolov B.S. №2013128714/03; zajavl. 24.06.2013; opubl. 10.06.2014.

2. Sokolov B.S., Fabrichnaya K.A. K Sstroitel'stvu Ekoshkol s Ispol'zovaniyem Universal'noy Industrial'noy Karkasnoy Sistemy Stroitel'stva UIKSS-Tatarstan [The Construction of Eco-Schools Using a Universal Industrial Frame Construction System UIFCS-Tatarstan]. // Zhilishchnoye stroitel'stvo, 2015, No. 2, pp. 9-13.

3. Sokolov B.S., Fabrichnaya K.A. Primeneniye Karkasnoy Sistemy UIKSS pri Rekonstruktsii Zdaniy [The Use of the UIKSS Framework System at Reconstruction of Buildings]. // Vestnik grazhdanskikh inzhenerov, 2015, No. 6(53), pp. 45-51.

4. Sokolov B.S., Troshkov E.O. Deformativnost' Shtepsel'nykh Stykov Sbornykh 
Dissipative Systems Computer Modelling of the Stress-Strain State of Plug-In Connections of Reinforced Concrete Columns with the Coverage Plates Under the Out-of-Square Eccentric Compression

Zhelezobetonnykh Plit Perekrytiy s Kolonnami $v$ Nesushchey Sisteme UIKSS [The Ddeformability of Plug-In Joints of Prefabricated Reinforced Concrete Slabs and Columns in the UIKSS Structural Floor System]. // Vestnik grazhdanskikh inzhenerov, 2017, No. 3(62), pp. 32-39.

5. Sokolov B.S., Troshkov E.O. Sravneniye Rezul'tatov Komp'yuternogo Modelirovaniya i Eksperimental'nykh Issledovaniy Shtepsel'nykh Stykov Sbornykh Zhelezobetonnykh Kolonn s Plitami Perekrytiy [Comparison of Computer Simulation and Experimental Studies of Socket Joints of Precast Reinforced Concrete Columns with Floor Slabs]. // Zhilishchnoye stroitel'stvo, 2017, No. 7, pp. 41-46.

6. Evdokimova T.S., Morozov V.I. Eksperimental'nyye Issledovaniya Kososzhimayemykh Zhelezobetonnykh i Fibrozhelezobetonnykh Elementov [Experimental investigations of reinforced concrete and fiber reinforced concrete members under biaxial] // Vestnik grazhdanskikh inzhenerov, 2015, No. 6 (53), pp. 37-41.

7. Evdokimova T.S. Prakticheskiy Metod rascheta Kososzhimayemykh Fibrozhelezobetonnykh Elementov [Practical Method of Calculating Fiber Reinforced Concrete Members Under Biaxial Compression] // Vestnik grazhdanskikh inzhenerov, 2015, No. 3 (50), pp. 68-74.

8. Geniyev G.A., Kissyuk V.N., Tyupin G.A. Teoriya Plastichnosti Betona i Zhelezobetona [Theory of Plasticity of Concrete and Reinforced Concrete]. Moscow, Stroyizdat, 1974.

9. SP 63.13330-2012. Betonnyye i Zzhelezobetonnyye Konstruktsii. Osnovnyye Polozheniya. Aktualizirovannaya Redaktsiya SNiP 52-01-2003 [Concrete and reinforced concrete structures. Basic provisions. Updated version of SNiP 52-012003]. Moscow, NIIZHB, 2012.

10. Kholmyanskiy M.M. Beton i Zhelezobeton: Deformativnost' i Prochnost' [Concrete and Reinforced Concrete: Deformability and Strength]. M.: Stroyizdat, 1997.
11. Rzhanitsyn A.R. Sostavnyye Sterzhni i Plastinki [Composite rods and plates]. Moscow, Stroyizdat. 1986.

12. Matkov N.G. Bessvarnyye Sstyki Vnetsentrenno Szhatykh Kolonn s Obzhatiyem i Aankerovkoy Armatury Rastvorami [Uncreated Joints of Eccentrically Compressed Columns with Compression and Anchoring of Reinforcement by Solutions]. // Beton i zhelezobeton, 1998, No. 1.

13. Benin A.V., Semenov A.S., Semenov S.G., Mel'nikov B.E. Matematicheskoye Modelirovaniye Protsessa Razrusheniya Stsepleniya Armatury s Betonom. Chast' 1. Modeli s Uchetom Nesploshnosti Soyedineniya [Simulation of Degradation of Bond Between Reinforcing Bar and Concrete. Part 1. Models with account of the discontinuity] // Inzhenerno-stroitel'nyy zhurnal, 2013, No. 5, pp. 86-99.

14. Benin A.V. Semenov A.S., Semenov S.G., Mel'nikov B.E. Matematicheskoye Modelirovaniye Protsessa Razrusheniya Stsepleniya Armatury s Betonom. Chast' 2. Modeli bez Ucheta Nesploshnosti Soyedineniya [The Simulation of Bond Fracture between Reinforcing Bars and concrete. Part 2. Models Without Taking the Bond Discontinuity into Account] // Inzhenernostroitel'nyy zhurnal, 2014, No. 1, pp. 23-40.

15. Tikhomirov V.M., Astakhov Y.V., Samoshkin A.S. Modelirovaniye Uprugoplasticheskogo Stsepleniya Armatury s Betonom [Modeling of Elastoplastic coupling of Reinforcement with Concrete] // Izvestiya vuzov. Stroitel'stvo, 2015, No. 2, pp. 103-109.

16. Sokolov B.S. Teoriya Silovogo Soprotivleniya Anizotropnykh Materialov Szhatiyu i yeye Prakticheskoye Primeneniye [Theory of force resistance of anisotropic materials to compression and its practical application: monograph]. Moscow, Izd-vo ASV, 2011, 160 pages. 


\section{СПИСОК ЛИТЕРАТУРЫ}

1. Патент 141473 Российская Федерация, МПК Е04В1/20 U1. Универсальная индустриальная каркасная система строительства - Татарстан (УИКССТатарстан) / Соколов Б.С.; заявитель и патентообладатель Соколов Б.С. №2013128714/03; $\quad$ заявл. 24.06.2013; опубл. 10.06.2014, Бюл. №16. - 2 с.

2. Соколов Б.С., Фабричная К.А. К строительству экошкол с использованием универсальной индустриальной каркасной системы строительства УИКСС-Татарстан. // Жилищное строительство, 2015, №2, с. 9-13.

3. Соколов Б.С., Фабричная К.А. Применение каркасной системы УИКСС при реконструкции зданий. // Вестник гражданских инженеров, 2015, №6(53), с. 45-51.

4. Соколов Б.С., Трошков Е.О. Деформативность штепсельных стыков сборных железобетонных плит перекрытий c колоннами в несущей системе УИКСС. // Вестник гражданских инженеров, 2017, № 3(62), с. 32-39.

5. Соколов Б.С., Трошков Е.О. Сравнение результатов компьютерного моделирования и экспериментальных исследований штепсельных стыков сборных железобетонных колонн с плитами перекрытий. // Жилищное строительство, 2017, № 7, с. 41-46.

6. Евдокимова Т.С., Морозов В.И. Экспериментальные исследования кососжимаемых железобетонных и фиброжелезобетонных элементов. // Вестник гражданских инженеров, 2015, №6 (53), с. 37-41.

7. Евдокимова Т.С. Практический метод расчета кососжимаемых фиброжелезобетонных элементов. // Вестник гражданских инженеров, 2015, №3 (50), c. 68-74.

8. Гениев Г.А., Киссюк В.Н., Тюпин Г.А. Теория пластичности бетона и железобетона. - М.: Стройиздат, 1974, $316 \mathrm{c}$.

9. СП 63.13330-2012. Бетонные и железобетонные конструкции. Основные положения. Актуализированная редакция СНиП 52-01-2003. - М.: НИИЖБ, 2012. $153 \mathrm{c}$.

10. Холмянский М.М. Бетон и железобетон: Деформативность и прочность. - М.: Стройиздат, 1997. - 576 с.

11. Ржаницын А.Р. Составные стержни и пластинки. - М.: Стройиздат. 1986.- 316 c.

12. Матков Н.Г. Бессварные стыки внецентренно сжатых колонн с обжатием и анкеровкой арматуры растворами. // Бетон и железобетон, 1998, № 1.

13. Бенин А.B., Семенов А.С., Семенов С.Г., Мельников Б.Е. Математическое моделирование процесса разрушения сцепления арматуры с бетоном. Часть 1. Модели с учетом несплошности соединения // Инженерно-строительный журнал, 2013, №5, с. 86-99.

14. Бенин А.В. Семенов А.С., Семенов С.Г., Мельников Б.Е. Математическое моделирование процесса разрушения сцепления арматуры с бетоном. Часть 2. Модели без учета несплошности соединения // Инженерно-строительный журнал, 2014, №1, c. 23-40.

15. Тихомиров В.М., Астахов Ю.В., Самошкин А.C. Моделирование упругопластического сцепления арматуры с бетоном. // Известия вузов. Строительство, 2015, №2, с. 103-109.

16. Соколов Б.С. Теория силового сопротивления анизотропных материалов сжатию и ее практическое применение: монография. - М.: Изд-во ACB, 2011. - 160 c.

Boris S. Sokolov, Corresponding Member of Russian Academy of Architecture and Construction Sciences, Dr.Sc., Professor; scientific consultant of JSC "Kazan Giproniiaviaprom"; 1, U1. Dementyeva, 420127, Kazan, Russia; phone $+7(919)$ 636-04-74; 
Dissipative Systems Computer Modelling of the Stress-Strain State of Plug-In Connections of Reinforced Concrete Columns with the Coverage Plates Under the Out-of-Square Eccentric Compression

E-mail: sbs.1942@mail.ru.

Evgeniy O. Troshkov, Candidate of Engineering Sciences; Senior Lecturer of Volga State University of Technology; 3, Pl. Lenina, 424000, Yoshkar-Ola, Russia; phone +7 (987) 711-57-87;

E-mail: troshkoveo@mail.ru.

Соколов Борис Сергеевич, член-корреспондент РА$\mathrm{ACH}$, профессор, доктор технических наук; научный консультант АО «Казанский Гипронииавиапром»; 420127, Россия, Республика Татарстан, г. Казань, ул. Дементьева, 1; тел. +7(919) 636-04-74;

E-mail: sbs.1942@mail.ru.

Трошков Евгений Олегович, кандидат технических наук; старший преподаватель, Поволжский государственный технологический университет; 424000, Россия, Республика Марий Эл, г. Йошкар-Ола, пл. Ленина, дом 3; тел. +7 (987) 711-57-87;

E-mail: troshkoveo@mail.ru. 